\title{
Temporal and spatial trends in precipitation chemistry in the Georgia Basin, British Columbia
}

\author{
Julian AHERNE*, Alyse MONGEON and Shaun A. WATMOUGH \\ Environmental and Resource Studies, Trent University, 1600 West Bank Drive, Peterborough, ON K9J 7B8, Canada \\ *e-mail corresponding author: julian.aherne@ucd.ie
}

\begin{abstract}
During the 1960s and 1970s, scientific evidence on the impacts of atmospheric acid deposition led to international negotiations to control emissions of compounds (primarily sulphur (S) and nitrogen (N) oxides) that undergo long-range transport. More recently, there has been growing interest in acid rain research in western Canada, e.g., the Georgia Basin, British Columbia, where $S$ and $N$ emissions are expected to increase during the next two decades. In the current study, long-term trends (1990-2007) in precipitation chemistry were evaluated at four stations (Saturna, British Columbia; Egbert, Ontario; Chapais Quebec; and Kejimkujik, Nova Scotia) using the Mann-Kendall statistical test. Precipitation chemistry at Saturna suggests that the Georgia Basin is less influenced by anthropogenic (S and N) emissions compared with monitoring stations in eastern Canada; nonetheless, long-term (1990-2007) trends in precipitation chemistry at Saturna [pH (significant increase) sulphate (significant decrease) and nitrate (decrease)] mirrored those at sites in eastern Canada suggesting all stations (across Canada) have responded similarly to large-scale emissions reductions under the Canada-United States Air Quality Agreement. The chemistry of precipitation and snow in the current study was well characterised by location and elevation, providing a way to estimate long-term mean annual base cation and chloride precipitation chemistry (ions showing no trend) at unmonitored sites for contiguous regions in the Georgia Basin.
\end{abstract}

Key words: trend analysis, regression modelling, sulphur and nitrogen, base cations, Canada

\section{INTRODUCTION}

During the 1960s and 1970s, scientific evidence on the impacts of atmospheric acid deposition led to international negotiations to control emissions of compounds (primarily sulphur $(\mathrm{S})$ and nitrogen $(\mathrm{N})$ oxides) that undergo long-range transport. The United Nations Economic Commission for Europe's Convention on Longrange Transboundary Air Pollution and the CanadaUnited States (US) Air Quality Agreement (AQA), are key international instruments in this respect. In concert, national agencies and institutions throughout Europe and North America established extensive programmes monitoring the chemical composition of precipitation to determine the extent of the problem and assess the efficiency of emission reduction policies.

Acid ( $\mathrm{S}$ and $\mathrm{N}$ ) rain research in Canada has primarily focused on eastern provinces owing to the historically high levels of deposition. Accordingly, federal programmes monitoring precipitation chemistry were concentrated in eastern Canada, while western provinces were supported by provincial programmes. Across Canada (especially western Canada), the number of monitoring stations has decreased in recent years owing to changes in financial and political priorities. During the late 1980s and early 1990s there were approximately fifteen monitoring stations in the Georgia Basin, British Columbia; only one monitoring station is still in operation [Saturna Island, operated by the Canadian Air and Precipitation Monitoring Network
(CAPMoN)]. While regional or continental-scale air quality models, such as AURAMS (A Unified Regional Air quality Modelling System: Moran et al. 2008), are being used to fill in the gaps in monitoring networks across western Canada for $\mathrm{S}$ and $\mathrm{N}$ deposition, these models do not predict base cation [calcium $\left(\mathrm{Ca}^{2+}\right)$, magnesium $\left(\mathrm{Mg}^{2+}\right)$, potassium $\left(\mathrm{K}^{+}\right)$and sodium $\left.\left(\mathrm{Na}^{+}\right)\right]$or chloride $\left(\mathrm{Cl}^{-}\right)$deposition. The (historic) spatial pattern in deposition may also be estimated by interpolating (e.g., kriging) observed precipitation concentrations; however, there are too few stations across western Canada, especially for complex (mountainous) regions such as the Georgia Basin.

In recent years there has been growing (or revived) interest on the impacts of $\mathrm{S}$ and $\mathrm{N}$ deposition in western Canada (e.g., Georgia Basin) where anthropogenic emissions are expected to increase owing to the expansion of the transport sector (road vehicles and marine vessels), industry and urban centres (GVRD 2003; Environment Canada 2004). In addition to local pollutant emission sources, the Georgia Basin receives transboundary emissions from the US. There is concern that acid sensitive soils and surface waters in the Georgia Basin are at risk of acidification from atmospheric acid deposition (Wiens 1987; Mongeon et al. 2010, this issue; Strang et al. 2010, this issue).

The objective of this study was to evaluate the longterm trends in precipitation chemistry in the Georgia Basin compared with eastern Canada and to assess spatial patterns across the study region. The long-term trends 
Tab. 1. Site ID (name and province), location (longitude, latitude), elevation, rainfall volume and five-year volume-weighted mean annual concentrations (2003-2007) for Canadian Air and Precipitation Monitoring Network stations.

\begin{tabular}{|c|c|c|c|c|c|c|c|c|c|c|c|c|c|}
\hline \multirow[t]{2}{*}{ ID (Station, province) } & Latitude & Longitude & \multirow{2}{*}{$\begin{array}{l}\text { Elev. } \\
\text { (m) }\end{array}$} & \multirow{2}{*}{$\begin{array}{l}\text { Vol. } \\
(\mathrm{cm})\end{array}$} & $\mathrm{pH}$ & $\mathrm{SO}_{4}{ }^{2-}$ & $\mathrm{NO}_{3}{ }^{-}$ & $\mathrm{Cl}^{-}$ & $\mathrm{NH}_{4}{ }^{+}$ & $\mathrm{Na}^{+}$ & $\mathrm{Ca}^{2+}$ & $\mathrm{Mg}^{2+}$ & $\mathrm{K}^{+}$ \\
\hline & (Decim & degrees) & & & \multicolumn{9}{|c|}{$\left(\mathrm{mg} \mathrm{L}^{-1}\right)$} \\
\hline SAT (Saturna, BC) & 48.783 & -123.133 & 178 & 83.8 & 4.90 & 0.64 & 0.66 & 1.38 & 0.10 & 0.77 & 0.07 & 0.10 & 0.04 \\
\hline EGB (Egbert, ON) & 44.233 & -79.781 & 253 & 81.2 & 4.62 & 1.68 & 1.68 & 0.12 & 0.46 & 0.05 & 0.25 & 0.04 & 0.02 \\
\hline CPS (Chapais, QC) & 49.822 & -74.976 & 381 & 108.9 & 4.81 & 0.77 & 0.72 & 0.05 & 0.18 & 0.02 & 0.07 & 0.01 & 0.02 \\
\hline KEJ (Kejimkujik, NS) & 44.434 & -65.206 & 127 & 151.0 & 4.81 & 0.81 & 0.58 & 1.16 & 0.11 & 0.65 & 0.06 & 0.08 & 0.03 \\
\hline
\end{tabular}

(1990-2007) in precipitation chemistry were evaluated at four CAPMoN stations (Saturna, British Columbia; Egbert, Ontario; Chapais Quebec; and Kejimkujik, Nova Scotia) using the Mann-Kendall statistical test (Gilbert 1987). The spatial pattern in (long-term) base cation and $\mathrm{Cl}^{-}$concentration data were evaluated using a polynomial regression modelling approach; this method was employed because of its ability to describe trend surfaces based on a limited number of stations while accounting for the influence of elevation.

\section{METHODS}

\subsection{Study area}

The Georgia Basin encompasses $48,000 \mathrm{~km}^{2}$ and is surrounded by four mountain ranges; Olympic mountains, Vancouver island ranges, Coast ranges and the Cascades. The area receives high levels of precipitation especially along the coastal regions as a result of orographic precipitation. Moreover, due to the variable topography, air masses and their associated pollutants can be trapped leading to potentially high atmospheric deposition. The major emitters of anthropogenic S and $\mathrm{N}$ within the basin include the marine, transportation, industrial and agricultural sectors (Environment Canada 2004).

\subsection{Precipitation chemistry data}

Volume-weighted mean annual precipitation chemistry data between 1990 and 2007 (18 years) were obtained from the Canadian National Atmospheric Chemistry (NAtChem) Database for the four CAPMoN stations (Tab. 1; URL: www.on.ec.gc.ca/natchem). Precipitation was sampled with wet-only collectors containing 24 hour integrated samples, replaced daily between 08:00 and 09:00 LST and refrigerated at $4{ }^{\circ} \mathrm{C}$ until chemical analyses $\left(\mathrm{pH}\right.$, sulphate $\left(\mathrm{SO}_{4}{ }^{2-}\right)$, nitrate $\left(\mathrm{NO}_{3}^{-}\right), \mathrm{Cl}^{-}$, ammonium $\left(\mathrm{NH}_{4}^{+}\right), \mathrm{Na}^{+}, \mathrm{Ca}^{2+}, \mathrm{Mg}^{2+}$ and $\left.\mathrm{K}^{+}\right)$. Non-sea salt $\mathrm{SO}_{4}{ }^{2-}$ concentrations for the coastal stations (Saturna and Kejimkujik) was estimated using theoretical sea-salt ratios and assuming that all $\mathrm{Cl}^{-}$in precipitation originated from sea-salt [e.g., (eq) ratio for $\mathrm{SO}_{4}{ }^{2-}: \mathrm{Cl}^{-}$is 0.103:1; UBA 2004]. In addition, base cation and $\mathrm{Cl}^{-}$precipitation chemistry data were collated from all available networks and stations within the Georgia Basin and Puget Sound (since 1978). Following quality control, data from ten stations were retained for analysis (Fig. 1.\& Tab. 2). However, the majority of the stations were located at low elevations $(<500 \mathrm{~m} \mathrm{ASL})$. To provide better representation at high elevations, precipitation chemistry was supplemented with snow chemistry data (McLaren 1982; D.P. Shaw, unpublished data) from six sites ranging in elevation from 1068 to 2299 m ASL (Fig. 1 \& Tab. 2).

\subsection{Trend analysis}

The non-parametric Mann-Kendall test (Gilbert 1987, Salmi 2002) was used to detect monotonic (increasing or decreasing) trends in time-series of annual volumeweighted precipitation concentrations for the four CAPMoN stations (Tab. 1) during the period 19902007. The Mann-Kendall test is widely used in environmental science for the detection of trends in timeseries data because it is simple, robust, accommodates missing values and data need not conform to any statistical distribution (Libiseller \& Grimvall 2002). The Mann-Kendall test does not estimate the slopes of trends, but it has become customary to associate slopes calculated according to Sen (1968), which are estimated as the median of all between-year differences in the variable of interest. A significance level of 0.05 was used to indicate statistically significant trends in the current study. Further, long-term trends in precipitation chemistry time-series were visually assessed following z-score transformation (i.e., mean of 0 and standard deviation of 1).

\subsection{Polynomial regression models}

The spatial pattern in mean annual long-term base cation and $\mathrm{Cl}^{-}$precipitation data was modelled using simple polynomial regression conditioned on location and elevation. Regression models have been widely used to relate precipitation chemistry and climate to spatial variables (e.g., Ollinger et al. 1995; Goodale et al. 1998; Aherne et al. 2002), as they are particularly useful for interpolating data where observations are limited. In the current study, (sixth-order trend surface) polynomial regression models of ion concentration (mg $\mathrm{L}^{-1}$ ) were based on easting and northing [in Albers projection $(\mathrm{km})]$ and elevation $(\mathrm{m})$ :

$$
\begin{gathered}
\text { Ion concentration }=b_{0}+b_{1} \times \text { Easting }+b_{2} \times \\
\times \text { Northing }+b_{3} \times \text { Easting }^{2}+b_{4} \times \text { Northing }^{2}+b_{5} \times \\
\times \text { Easting } \times \text { Northing }+b_{6} \times \text { Elevation }
\end{gathered}
$$

The $b$ coefficients were determined using leastsquares fitting between modelled and observed data. 


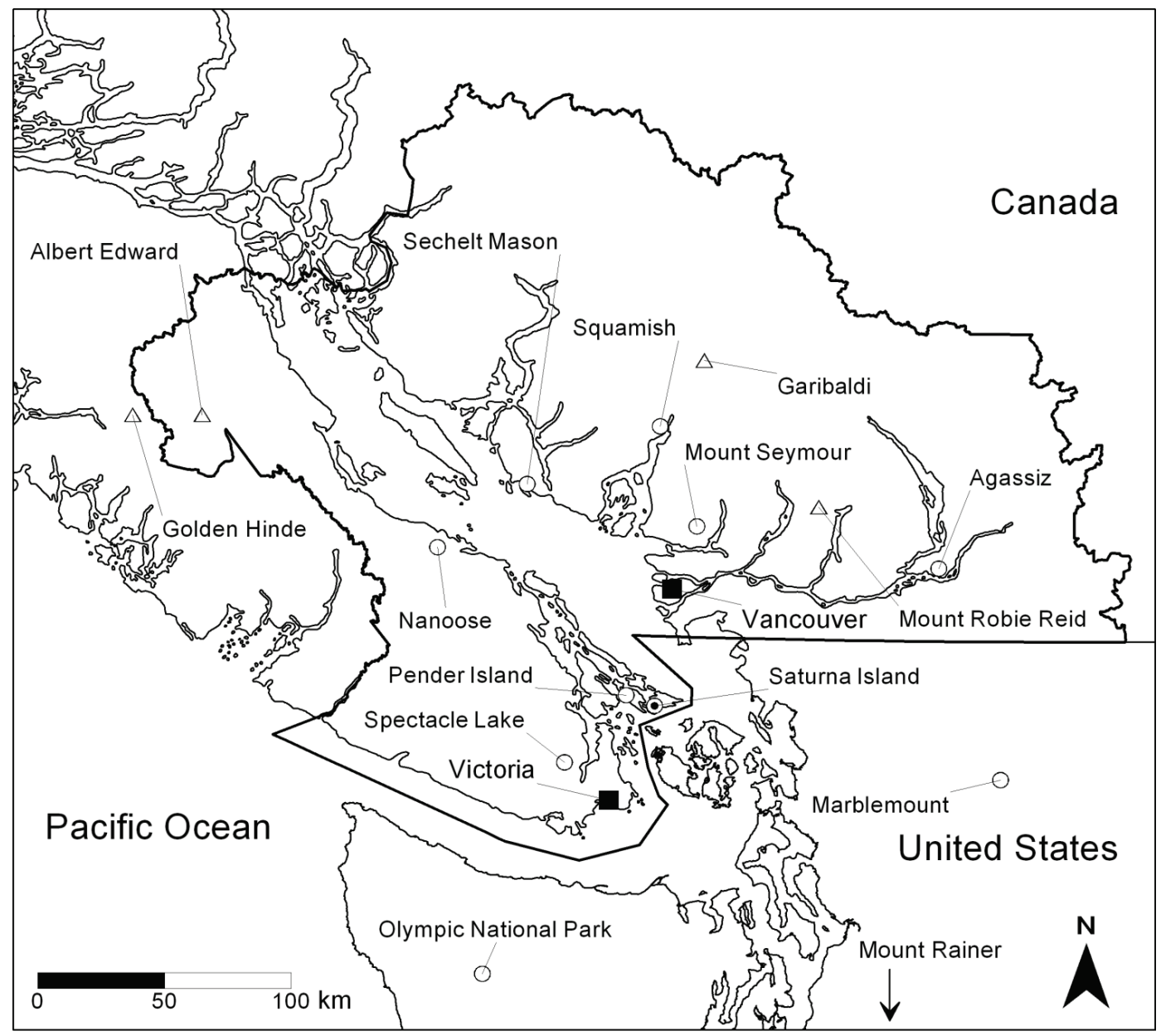

Fig. 1. Location of precipitation chemistry stations (circles; $n=10$ ), snow sampling sites (triangles; $n=6$ ) and the precipitation trend station (circle with bull's eye; Saturna) within (and outside) the Georgia Basin (thick black line). Cities are also shown (black squares). See tables $1 \& 2$ for further description of sampling stations.

Tab. 2. The location (Albers projection easting and northing), elevation and average annual concentration [for one or more years (Y)] for base cations and chloride in precipitation and snow chemistry (SN) in the Georgia Basin and Puget Sound. Precipitation chemistry data were obtained from two sources (SRC): British Columbia Precipitation Chemistry Sampling Network (BC) and National Atmospheric Deposition Program (NA).

\begin{tabular}{|c|c|c|c|c|c|c|c|c|c|c|}
\hline Site name & $\begin{array}{l}\text { East. } \\
(\mathrm{km})\end{array}$ & $\begin{array}{l}\text { North. } \\
(\mathrm{km})\end{array}$ & $\begin{array}{l}\text { Elev. } \\
(\mathrm{m})\end{array}$ & $\mathrm{Ca}^{2+}$ & $\mathrm{Mg}^{2+}$ & $\mathrm{K}^{+}$ & $\frac{\mathrm{Na}^{+}}{\left(\mathrm{mg} \mathrm{L}^{-1}\right)}$ & $\mathrm{Cl}^{-}$ & Y & SRC \\
\hline Agassiz & 590.2 & 5455.2 & 30 & 0.11 & 0.02 & 0.04 & 0.18 & 0.33 & 2 & $\mathrm{BC}$ \\
\hline Squamish & 489.1 & 5505.3 & 15 & 0.11 & 0.03 & 0.06 & 0.28 & 0.53 & 11 & $\mathrm{BC}$ \\
\hline Nanoose & 410.4 & 5458.7 & 100 & 0.11 & 0.04 & 0.10 & 0.39 & 0.69 & 9 & $\mathrm{BC}$ \\
\hline Sechelt Mason & 442.0 & 5482.8 & 125 & 0.12 & 0.04 & 0.07 & 0.34 & 0.55 & 2 & $\mathrm{BC}$ \\
\hline Spectacle Lake & 457.9 & 5380.1 & 380 & 0.11 & 0.08 & 0.07 & 0.62 & 1.10 & 6 & $\mathrm{BC}$ \\
\hline Mount Ranier & 567.1 & 5179.0 & 421 & 0.02 & 0.02 & 0.01 & 0.15 & 0.27 & 4 & NA \\
\hline Marblemount & 614.3 & 5377.5 & 123 & 0.03 & 0.02 & 0.01 & 0.13 & 0.24 & 19 & NA \\
\hline Olympic Park & 430.3 & 5301.1 & 176 & 0.04 & 0.06 & 0.02 & 0.54 & 0.97 & 22 & NA \\
\hline Pender Island & 479.7 & 5405.4 & 30 & 0.10 & 0.06 & 0.08 & 0.55 & 1.00 & 5 & $\mathrm{BC}$ \\
\hline Mt Seymour & 502.8 & 5467.0 & 866 & 0.05 & 0.03 & 0.07 & 0.25 & 0.37 & 2 & $\mathrm{BC}$ \\
\hline Mt Seymour & 503.2 & 5468.4 & 1068 & 0.04 & 0.02 & & & 0.30 & 1 & SN \\
\hline Mt Robie Reid & 546.7 & 5476.7 & 1464 & 0.03 & 0.02 & & 0.11 & 0.26 & 1 & SN \\
\hline Albert Edward & 325.1 & 5505.5 & 1935 & 0.02 & 0.03 & 0.01 & 0.16 & 0.32 & 1 & SN \\
\hline Golden Hinde I & 300.2 & 5504.9 & 1762 & 0.02 & 0.02 & 0.01 & 0.16 & 0.30 & 1 & SN \\
\hline Golden Hinde II & 300.8 & 5502.5 & 1230 & 0.02 & 0.04 & 0.01 & 0.29 & 0.54 & 1 & SN \\
\hline Garibaldi & 504.3 & 5529.9 & 2299 & 0.02 & 0.01 & 0.01 & 0.01 & 0.06 & 1 & SN \\
\hline
\end{tabular}


Tab. 3. Mann-Kendall trend statistic $(Z)$ in precipitation volume and chemistry (concentration) for the period 1990-2007 and delta $(\Delta)$ change in ion concentration $\left(\mu \mathrm{eq} \mathrm{L}^{-1}\right)$ for the 18 year period based on the Sen slope (Sen 1968) for SAT (Saturna, British Columbia), EGB (Egbert, Ontario), CPS (Chapais, Quebec) and KEJ (Kejimkujik, Nova Scotia). The Z-statistic indicates significant decreasing $(Z<-1.96, p<0.05)$ and increasing $(Z>1.96, p<0.05)$ trends. Non-sea salt (nss) was estimated using theoretical sea-salt ratios and assuming that all $\mathrm{Cl}^{-}$in precipitation originated from sea-salt [(eq) ratio for $\mathrm{SO}_{4}{ }^{2-}: \mathrm{Cl}^{-}$is $0.103: 1$; UBA 2004].

\begin{tabular}{|c|c|c|c|c|c|c|c|c|}
\hline & \multicolumn{2}{|c|}{ SAT } & \multicolumn{2}{|c|}{ EGB } & \multicolumn{2}{|c|}{ CPS } & \multicolumn{2}{|c|}{ KEJ } \\
\hline & Z & $\Delta$ & Z & $\Delta$ & Z & $\Delta$ & Z & $\Delta$ \\
\hline Volume & 0.00 & & -0.68 & & -0.34 & & 0.15 & \\
\hline $\mathrm{pH}$ & 3.46 & & 4.42 & & 4.29 & & 3.30 & \\
\hline $\mathrm{nSSSO}_{4}{ }^{2-}$ & -3.22 & & -3.34 & & -2.88 & & -2.27 & \\
\hline $\mathrm{H}^{+}$ & -3.41 & -10.21 & -4.47 & -28.09 & -4.32 & -15.00 & -3.30 & -10.72 \\
\hline $\mathrm{SO}_{4}{ }^{2-}$ & -2.92 & -6.12 & -3.34 & -14.89 & -2.88 & -10.20 & -2.08 & -3.40 \\
\hline $\mathrm{NO}_{3}^{-}$ & -1.55 & -3.03 & -2.05 & -6.70 & -2.01 & -4.25 & -1.82 & -2.40 \\
\hline $\mathrm{Cl}^{-}$ & 0.38 & 2.84 & 0.11 & 0.05 & -1.71 & -0.25 & 0.68 & 5.35 \\
\hline $\mathrm{NH}_{4}^{+}$ & -1.18 & -1.07 & 0.83 & 2.30 & 0.53 & 1.00 & 2.08 & 1.60 \\
\hline $\mathrm{Na}^{+}$ & 0.23 & 2.54 & 3.31 & 0.91 & -1.65 & -0.20 & 0.83 & 3.45 \\
\hline $\mathrm{Ca}^{2+}$ & 1.03 & 0.45 & 0.87 & 2.36 & 1.86 & 1.07 & 1.98 & 0.84 \\
\hline $\mathrm{Mg}^{2+}$ & 0.27 & 0.30 & 0.00 & 0.00 & -1.37 & -0.12 & 0.72 & 1.18 \\
\hline $\mathrm{K}^{+}$ & 1.03 & 0.15 & 0.08 & 0.00 & 0.15 & 0.00 & 0.99 & 0.15 \\
\hline$\Sigma$ Cations & & -7.84 & & -22.52 & & -13.26 & & -3.49 \\
\hline$\Sigma$ Anions & & -6.31 & & -21.54 & & -14.70 & & -0.46 \\
\hline Balance & & -1.53 & & -0.98 & & 1.45 & & -3.04 \\
\hline
\end{tabular}

In several cases, terms were removed to improve fitting and maximise $R^{2}$ values resulting in simpler models. The regression models were conditioned on long-term mean annual base cation and $\mathrm{Cl}^{-}$data as it was assumed that concentrations did not change significantly over time. Sulphate, $\mathrm{NO}_{3}{ }^{-}$and $\mathrm{NH}_{4}{ }^{+}$were excluded from this analysis as their long-term spatial patterns are significantly influenced by changes in anthropogenic emissions.

\section{RESULTS AND DISCUSSION}

\subsection{Precipitation chemistry}

Current (volume-weighted) mean annual precipitation chemistry (2003-2007) at Saturna was less influenced by anthropogenic ( $\mathrm{S}$ and $\mathrm{N}$ ) emissions compared with monitoring stations in Ontario (Egbert), Quebec (Chapais) and Nova Scotia (Kejimkujik). Saturna had the highest $\mathrm{pH}(4.90)$ and lowest non-sea salt $\mathrm{SO}_{4}{ }^{2-}$ concentration $\left(0.44 \mathrm{mg} \mathrm{L}^{-1}\right)$ compared with the stations in eastern Canada. This is expected as Egbert, Chapais and Kejimkujik are located downwind of the largest emissions sources in north America; moreover, Egbert is located in an agricultural region adjacent to the largest industrialised region in eastern Canada (Egbert $\mathrm{pH}=$ 4.62 and non-sea salt $\mathrm{SO}_{4}{ }^{2-}=1.68 \mathrm{mg} \mathrm{L}^{-1}$; Tab. 1). Nitrate precipitation concentrations were more comparable across stations (Tab. 1); however, Saturna received the lowest $\mathrm{NO}_{3}{ }^{-}$deposition owing to low precipitation volume $[83.8 \mathrm{~cm}$, range of 81.2 (Egbert)-151.0 (Kejimkujik) cm]. Similarly, Saturna observed the lowest $\mathrm{SO}_{4}{ }^{2-}$ deposition $\left(7.7 \mathrm{meq} \mathrm{m}{ }^{-2} \mathrm{y}^{-1}\right)$, approximately a quarter of Egbert (28.4 meq m $\left.\mathrm{m}^{-2} \mathrm{y}^{-1}\right)$ and a third of Kejimkujik $\left(20.2 \mathrm{meq} \mathrm{m}^{-2} \mathrm{y}^{-1}\right)$. Saturna also has the weakest agricultural signal, as indicated by the low(est)
$\mathrm{NH}_{4}^{+}$concentrations (Tab. 1). In contrast, precipitation chemistry at Saturna (and Kejimkujik) was dominated by marine inputs (highest concentrations of $\mathrm{Na}^{+}, \mathrm{Cl}^{-}$and $\mathrm{Mg}^{2+}$ ) owing to the(ir) coastal proximity.

\subsection{Long-term trends}

There was a highly significant increasing trend in long-term (1990-2007) annual $\mathrm{pH}$ and a decreasing trend in (non-sea salt) $\mathrm{SO}_{4}{ }^{2-}$ at Saturna; these trends were consistent with observations at the University of British Columbia Research Forest, Georgia Basin (Feller 2010, this issue) and with the three stations in eastern Canada (Tab. 3). Despite differences in precipitation chemistry (Tab. 1), the time-series trends were synchronous (Fig. 2), suggesting all stations (across Canada) have responded similarly to the large-scale emissions reductions under the Canada-US AQA. Similar responses were observed in the US during the period 1985-2002 (Lehmann et al. 2005), with significant decreases in $\mathrm{SO}_{4}{ }^{2-}$ at 139 stations (85\% of study sites). During the last two decades, emissions of $\mathrm{S}$ dioxide $\left(\mathrm{SO}_{2}\right)$ and $\mathrm{N}$ oxides $\left(\mathrm{NO}_{\times}\right)$from US electrical powerplants have decreased by a factor of 1.7 and 1.6, respectively (National Air Quality and Emissions Trends Reports, URL: www.epa.gov/ttn/chief/trends). The substantial reductions in power-plant $\mathrm{SO}_{2}$ emissions during the 1990s and $\mathrm{NO}_{\times}$emissions in the past decade are a direct result of pollutant-specific cap-and-trade control strategies mandated by the US Environmental Protection Agency's Acid Rain Program and $\mathrm{NO}_{\times}$Budget Trading Program (Monks et al. 2009). Total emissions from Canada and the US are dominated by the US, e.g., approximately $90 \%$ of total S emissions in eastern North America are from US sources (Vet \& Ro 2008). The reductions in $\mathrm{SO}_{2}$ emissions have resulted in an almost 

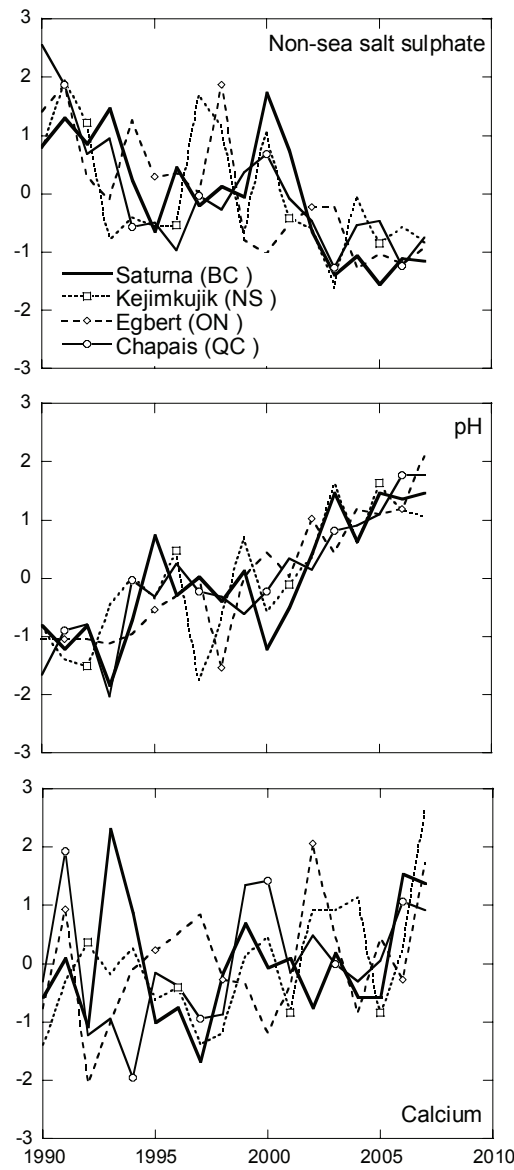
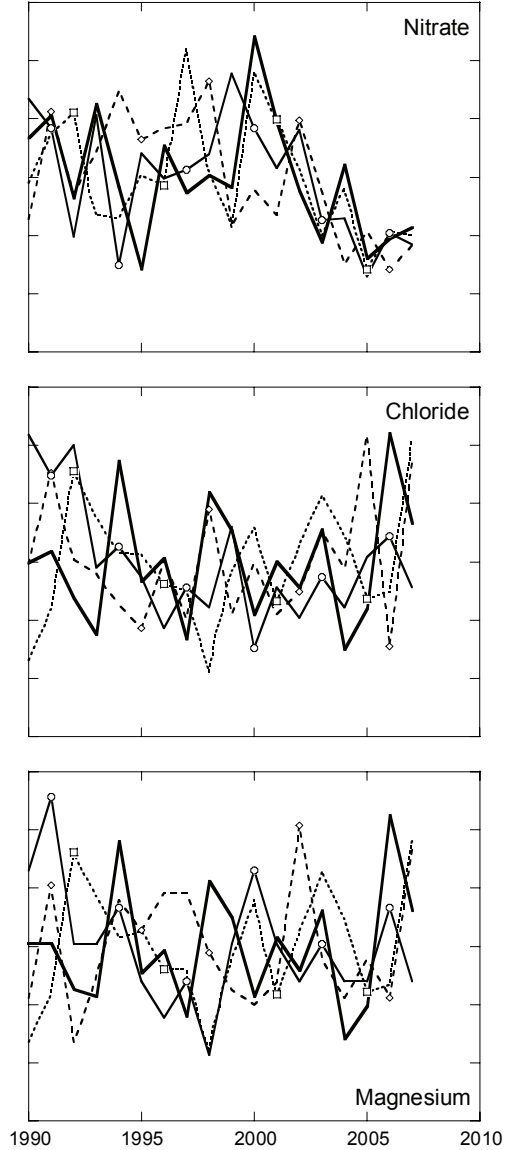
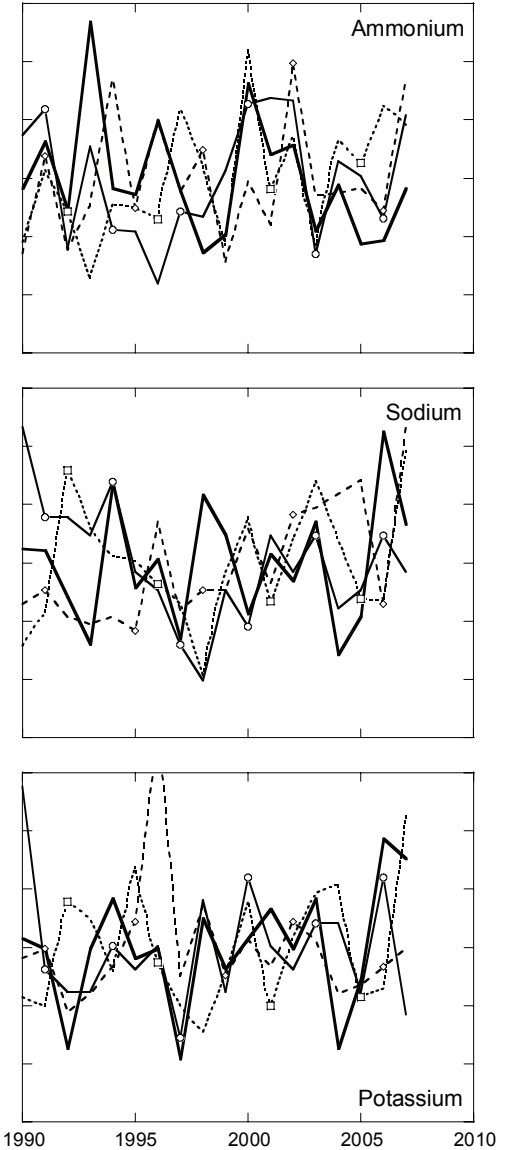

Fig. 2. Normalised (z-score) time-series of precipitation chemistry during the period 1990-2007 (18 years) for Saturna (British Columbia), Egbert (Ontario), Chapais (Quebec) and Kejimkujik (Nova Scotia). See table 1 for further description of sampling stations.

constant linear decrease in $\mathrm{SO}_{4}{ }^{2-}$ concentrations in precipitation (Fig. 2). A decreasing trend was also observed for $\mathrm{NO}_{3}^{-}$across all stations; however, statistically significant trends were only observed at Egbert and Chapais. Nonetheless, $\mathrm{NO}_{3}{ }^{-}$time-series showed a synchronous pattern, with static or slightly increasing concentrations between 1990 and 2000, and strong decreases thereafter (Fig. 2). This pattern is consistent with on-road vehicle emission inventories that show an increase in $\mathrm{NO}_{\times}$emissions throughout the 1990s (Parrish 2006), and with power-plant emissions inventories that show the largest reductions in $\mathrm{NO}_{\times}$after 1998 .

There were no consistent trends in $\mathrm{NH}_{4}{ }^{+}, \mathrm{Cl}^{-}, \mathrm{Na}^{+}$or $\mathrm{Mg}^{2+}$ between the four stations (Tab. 3 \& Fig. 2); the decreasing trend in $\mathrm{NH}_{4}^{+}$only observed at Saturna may be related to the depopulation of all poultry in the Fraser Valley, Georgia Basin (19 million birds), following an outbreak of avian influenza H7N3 in 2004, or a decrease in the long-range transport of ammonium bisulphate particles associated with reductions in $\mathrm{SO}_{2}$ emissions. An increasing trend in $\mathrm{Ca}^{2+}$ concentration was observed across all stations (statistically significant at Kejimkujik). This is in contrast to earlier studies that suggested decreases in $\mathrm{Ca}^{2+}$, in conjunction with decreases in
$\mathrm{SO}_{4}{ }^{2-}$ (during the 1970s and 1980s), offset any (expected) increases in precipitation $\mathrm{pH}$ (Hedin et al. 1994). Moreover, ionic balances for the four stations indicate that decreases in $\mathrm{SO}_{4}{ }^{2-}$ and $\mathrm{NO}_{3}{ }^{-}$(and to a lesser extent increases in $\mathrm{Ca}^{2+}$ and $\mathrm{NH}_{4}^{+}$) during 19902007 predominantly explain the increases in $\mathrm{pH}$ (decreases in hydrogen ion; Tab. 3). The largest change in ion concentrations was observed at Egbert (cations = $22.52 \mu \mathrm{eq} \mathrm{L} \mathrm{L}^{-1}$ and anions $=-21.54 \mu \mathrm{eq} \mathrm{L}^{-1}$ ), followed by Chapais, Saturna and Kejimkujik (Tab. 3). Limited changes and poor ion balances were observed at Kejimkujik due to the high variability in sea salt inputs $\left(\Delta \mathrm{Cl}^{-}\right.$ Tab. 3).

\subsection{Polynomial regression models}

The spatial pattern in base cations and $\mathrm{Cl}^{-}$was strongly related to location and elevation for the Georgia Basin (Tab. 4). The polynomial regression models explained between $74 \%\left(\mathrm{Ca}^{2+}\right)$ and $89 \%\left(\mathrm{Na}^{+}\right)$of the spatial variability in the observed data $(n=16$; Tab. $1 \&$ 4). The elevation coefficient was negative for all ions, indicating decreased concentration (dilution) with elevation (under higher precipitation volumes); $\mathrm{Cl}^{-}$was most strongly influenced by elevation, whereas $\mathrm{Mg}^{2+}$ was 
Tab. 4. Polynomial regression coefficients for predicting base cation and chloride precipitation concentrations from location [Albers projection easting and northing $(\mathrm{km})$ ] and elevation $(\mathrm{m}){ }^{\S}$. Adjusted $R^{2}$ is the coefficient of determination, adjusted for the complexity of the model relative to the complexity of the data. Base cation and chloride data are given in table 2 .

${ }^{\S}$ Concentration $=b_{0}+b_{1} \times$ Easting $+b_{2} \times$ Northing $+b_{3} \times$ Easting $^{2}+b_{4} \times$ Northing $^{2}+b_{5} \times$ Easting $\times$ Northing $+b_{6} \times$ Elevation.$^{2}$

\begin{tabular}{|c|c|c|c|c|c|c|c|c|}
\hline $\begin{array}{l}\text { Ion } \\
\mathrm{mg} \mathrm{L}^{-1}\end{array}$ & $\begin{array}{c}b_{0} \\
\text { Constant }\end{array}$ & $\begin{array}{c}b_{1} \\
\text { Easting }\end{array}$ & $\begin{array}{c}b_{2} \\
\text { Northing }\end{array}$ & $\begin{array}{c}b_{3} \\
\text { Easting }^{2}\end{array}$ & $\begin{array}{c}b_{4} \\
\text { Northing }^{2}\end{array}$ & $\begin{array}{c}b_{5} \\
\text { Easting } \times \text { Northing }\end{array}$ & $\begin{array}{c}b_{6} \\
\text { Elevation }\end{array}$ & $\begin{array}{c}\text { Adjusted } \\
R^{2}\end{array}$ \\
\hline Calcium & -1.40 & $0.12 \times 10^{-2}$ & $0.02 \times 10^{-2}$ & $-1.36 \times 10^{-6}$ & - & - & $-4.81 \times 10^{-5}$ & 73.6 \\
\hline Magnesium & -28.38 & $0.04 \times 10^{-2}$ & $1.07 \times 10^{-2}$ & $-6.37 \times 10^{-7}$ & $-1.00 \times 10^{-6}$ & - & $-7.03 \times 10^{-6}$ & 74.4 \\
\hline Potassium & -51.46 & $1.87 \times 10^{-2}$ & $1.73 \times 10^{-3}$ & $-3.06 \times 10^{-6}$ & $-1.47 \times 10^{-6}$ & $-2.92 \times 10-6$ & $-1.88 \times 10^{-5}$ & 80.4 \\
\hline Sodium & -240.78 & $0.55 \times 10^{-2}$ & $9.03 \times 10^{-2}$ & $-7.29 \times 10^{-6}$ & $-8.48 \times 10^{-6}$ & - & $-7.35 \times 10^{-5}$ & 88.8 \\
\hline Chloride & -415.65 & $9.10 \times 10^{-2}$ & $1.56 \times 10^{-2}$ & $-1.23 \times 10^{-5}$ & $-1.46 \times 10^{-5}$ & - & $-1.22 \times 10^{-4}$ & 82.7 \\
\hline
\end{tabular}

least (Tab. 4). Similarly, the sign of the location (easting and northing) and error (constant) coefficients were consistent for all models; all ion concentrations (generally) decreased with increasing easting and northing (Fig. $1 \&$ Tab. 4). Several model terms were removed to improve model fit, e.g., the easting $\times$ northing term was removed from most models. Two regression terms were removed from the $\mathrm{Ca}^{2+}$ model, indicative of different sources for this ion (and weaker influence from marine inputs).

Estimating precipitation chemistry for the Georgia Basin is difficult because of the varied topography and the limited monitoring stations. Furthermore, high elevation monitoring stations are rare because of logistics and operating costs. Precipitation chemistry at high elevations is difficult to model owing to uncertainties in cloud cover, precipitation amounts and associated chemistries. Nonetheless, the chemistry of precipitation and snow in the current study was well characterised by location and elevation, providing a way to estimate longterm annual base cation and $\mathrm{Cl}^{-}$precipitation chemistry at unmonitored (forest) plots for contiguous regions in the Georgia Basin (Mongeon et al. 2010, this issue).

\section{CONCLUSION}

Precipitation chemistry at Saturna suggests that the Georgia Basin is less influenced by anthropogenic (S and $\mathrm{N}$ ) emissions compared with monitoring stations in eastern Canada, and receives significantly lower nonsea salt $\mathrm{SO}_{4}{ }^{2-}$ deposition $\left(7.7 \mathrm{meq} \mathrm{m}{ }^{-2} \mathrm{y}^{-1}\right)$ compared with Egbert (28.4 meq $\left.\mathrm{m}^{-2} \mathrm{y}^{-1}\right)$ and Kejimkujik (20.2 meq $\left.\mathrm{m}^{-2} \mathrm{y}^{-1}\right)$. Nonetheless, long-term (1990-2007) trends in precipitation chemistry $\left(\mathrm{pH}, \mathrm{SO}_{4}{ }^{2-}\right.$ and $\left.\mathrm{NO}_{3}{ }^{-}\right)$ at Saturna mirrored those at sites in eastern Canada suggesting all stations (across Canada) have responded similarly to large-scale emissions reductions under the Canada-US AQA. Moreover, the time-series of $\mathrm{SO}_{4}{ }^{2-}$ and $\mathrm{NO}_{3}^{-}$at the four CAPMoN stations were highly consistent with $\mathrm{SO}_{2}$ and $\mathrm{NO}_{\times}$emissions inventories for US electrical power-plants and on-road vehicles.

Precipitation chemistry in the Georgia Basin was dominated by marine ions (e.g., $\mathrm{Na}^{+}, \mathrm{Mg}^{2+}$ and $\mathrm{Cl}^{-}$); their spatial pattern [and similarly for (non-sea salt) base cations] was strongly related to location (proximity to the ocean) and elevation (dilution). Polynomial regression models based on these independent variables explained between $74 \%\left(\mathrm{Ca}^{2+}\right)$ and $89 \%\left(\mathrm{Na}^{+}\right)$of the variability in observed data, providing a way to estimate base cation and $\mathrm{Cl}^{-}$precipitation chemistry at unmonitored sites for contiguous regions of the Georgia Basin.

\section{ACKNOWLEDGEMENTS}

Financial support for this study was provided by the Georgia Basin Action Plan and Environment Canada Pacific and Yukon Region. This research was undertaken, in part, thanks to funding from the Canada Research Chairs Program and a Natural Sciences and Engineering Research Council of Canada Discovery grant. The authors acknowledge the Canadian National Atmospheric Chemistry (NAtChem) Database and its data contributing agencies / organisations for the provision of the data, used in this publication. This article is dedicated to the late Beverley A. Raymond, Environment Canada, for her motivation and foresight to initiate critical loads research in the Georgia Basin.

\section{REFERENCES}

Aherne, J. \& E.P. Farrell. 2002. Deposition of sulphur, nitrogen and acidity in precipitation over Ireland: chemistry, spatial variation and long-term trends. Atmos. Environ., 36: 1379-1389.

Environment Canada. 2004. Canadian acid deposition science assessment. Meteorological Service of Canada, Ottawa, Ontario: $440 \mathrm{pp}$.

Feller, M.C. 2010. Trends in precipitation and streamwater chemistry in East Creek watershed in southwestern British Columbia, 1971-2008. J. Limnol., 69(Suppl. 1): 77-91. DOI: 10.3274/JL10-69-S1-09.

Gilbert, R.O. 1987. Statistical methods for environmental pollution monitoring. Van Nostrand Reinhold, New York: $336 \mathrm{pp}$.

Goodale, C., J. Aber \& S. Ollinger. 1998. Mapping monthly precipitation, temperature, and solar radiation for Ireland with polynomial regression and a digital elevation model. Clim. Res., 10: 35-49.

GVRD. 2003. Forecast and backcast of the 2000 emission inventory for the Lower Fraser Valley Airshed 1985-2025. Greater Vancouver Regional District, Policy \& Planning Department: $38 \mathrm{pp}$.

Hedin, L.O., L. Granat, G.E. Likens, T.A. Buishand, J.N. Galloway, T.J. Butler \& H. Rodhe. 1994. Steep declines in 
atmospheric base cations in regions of Europe and North America. Nature, 367: 351-354.

Lehmann, C.M.B., V.C Bowersox \& S.M. Larson. 2005. Spatial and temporal trends of precipitation chemistry in the United States, 1985-2002. Environ. Pollut., 135: 347-361.

Libiseller, C. \& A. Grimval. 2002. Performance of partial Mann-Kendall test for trend detection in the presence of covariates. Environmetrics, 13: 71-84.

McLaren, R. 1982. Sampling of snowpack for chemical analysis in southwestern British Columbia. Internal report: Environment Canada Atmospheric Environment Service Report PAES 82-3.

Mongeon, A., J. Aherne \& S.A. Watmough. 2010. Steadystate critical loads of acidity for forest soils in the Georgia Basin, British Columbia. J. Limnol., 69(Suppl. 1): 193200. DOI: $10.3274 / J L 10-69-S 1-19$.

Monks P.S., C. Granier, S. Fuzzi, A. Stohl, M.L. Williams, H. Akimoto, M. Amann, A. Baklanov, U. Baltensperger, I. Bey, N. Blake, R.S. Blake, K. Carslaw, O.R. Cooper, F. Dentener, D. Fowler, E. Fragkou, G.J. Frost, S. Generoso, P. Ginoux, V. Grewe, A. Guenther, H.C. Hansson, S. Henne, J. Hjorth, A. Hofzumahaus, H. Huntrieser, I.S.A. Isaksen, M.E. Jenkin, J. Kaiser, M. Kanakidou, Z. Klimont, M. Kulmala, P. Laj, M.G. Lawrence, J.D. Lee, C. Liousse, M. Maione, G. McFiggans, A. Metzger, A. Mieville, N. Moussiopoulos, J.J. Orlando, C.D. O'Dowd, P.I. Palmer, D.D. Parrish, A. Petzold, U. Platt, U. Pöschl, A.S.H. Prévôt, C.E. Reeves, S. Reimann, Y. Rudich, K. Sellegri, R. Steinbrecher, D. Simpson, H. ten Brink, J. Theloke, G.R. van der Werf, R. Vautard, V. Vestreng, Ch. Vlachokostas \& R. von Glasow. 2009. Atmospheric composition change - global and regional air quality. Atmos. Environ., 43: 5268-5350.

Moran, M.D., Q. Zheng, R. Pavlovic, S. Cousineau, V.S. Bouchet, M. Sassi, P.A. Makar, W. Gong \& C. Stroud. 2008. Predicted acid deposition critical-load exceedances across Canada from a one-year simulation with a regional particulate-matter model. Proceedings of the 15th Joint
AMS/A\&WMA Conference on Applications of Air Pollution Meteorology, January 21-24, New Orleans, American Meteorological Society, Boston: $20 \mathrm{pp}$.

Ollinger, S., J. Aber, C. Federer, G. Lovett \& J. Ellis. 1995. Modelling physical and chemical climate of the northeastern United States for a Geographic information system. Gen. Tech. Rep. NE-191. US Department of Agriculture, Forest Service, Northeastern Forest Experiment Station: $30 \mathrm{pp}$.

Parrish, D. 2006. Critical evaluation of US on-road vehicle emission inventories. Atmos. Environ., 40: 2288-2300.

Salmi, T., A. Määttä, P. Anttila, T. Ruoho-Airola \& T. Amnell. 2002. Detecting trends of annual values of atmospheric pollutants by the Mann-Kendall test and Sen's slope estimates - the excel template application MAKESENS. Publications on air quality No. 31, Finnish Meteorological Institute, Helsinki: $35 \mathrm{pp}$.

Sen, P.K. 1968. Estimates of the regression coefficient base on Kendall's Tau. J. Amer. Statis. Assn., 63: 1379-1389.

Strang, D., J. Aherne \& D.P. Shaw. 2010. The hydrochemistry of high-elevation lakes in the Georgia Basin, British Columbia. J. Limnol., 69 (Suppl. 1): 56-66. DOI: 10.3274/ JL10-69-S1-07.

UBA 2004. Manual on methodologies and criteria for modelling and mapping critical loads \& levels and air pollution effects, risks and trends. UNECE Convention on Longrange Transboundary Air Pollution, Federal Environmental Agency (Umweltbundesamt), Berlin: $254 \mathrm{pp}$.

Vet, R. \& C.-U. Ro. 2008. Contribution of Canada-United States transboundary transport to wet deposition of sulphur and nitrogen oxides-A mass balance approach. Atmos. Environ., 42: 2518-2529.

Wiens, J.H. 1987. Sensitivity of western and northern Canada soils and geology to acidic input. Victoria, B.C.: Technical Committee for the Long-Range Transport of Atmospheric Pollutants in Western and Northern Canada, Coordinating Committee on Soil and Geology Sensitivity Mapping, Canada. 